\title{
Targeted genome modification in protoplasts of a highly regenerable Siberian barley cultivar using RNA-guided Cas9 endonuclease
}

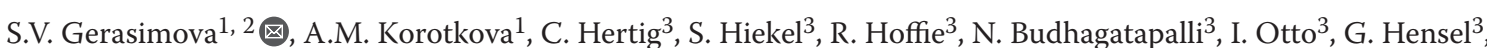
V.K. Shumny ${ }^{1}$, A.V. Kochetov ${ }^{1,2}$, J. Kumlehn ${ }^{3}$, E.K. Khlestkina ${ }^{1,2,} 4$

\footnotetext{
${ }^{1}$ Institute of Cytology and Genetics, SB RAS, Novosibirsk, Russia

2 Novosibirsk State University, Novosibirsk, Russia

${ }^{3}$ Leibniz-Institut für Pflanzengenetik und Kulturpflanzenforschung (IPK), Gatersleben, Germany

${ }^{4}$ N.I. Vavilov All-Russian Research Institute of Plant Genetic Resources (VIR), St. Petersburg, Russia
}

The modification of crop genomes employing functional components of the microbial CRISPR/Cas immune system is a rapidly developing area of applied research. Site-directed plant genome modification by this technology involves the construction of Cas endonuclease- and guide-RNA-encoding vectors, delivery of the plasmid DNA into plant cells, processing of the chosen genomic target site by the corresponding gene products and regeneration of plants from modified cells. The utilization of this technology in local breeding programs is mainly limited by the typically strong genotype dependence of gene transfer and in vitro regeneration procedures, which holds particularly true in cereals. In the present study, an evaluation of in vitro regeneration efficiency of immature embryos of ten Siberian barley cultivars revealed that only one of these is on a par with the experimental standard cultivar Golden Promise. This cultivar, namely cv. Aley, was consequently chosen for further experiments on site-directed mutagenesis in leaf mesophyll protoplasts. Two genes controlling hulled vs naked (Nud) and two-rowed vs six-rowed barley (Vrs1) were used as targets to be modified via polyethyleneglycol-mediated cellular uptake of guide-RNA/Cas9-encoding plasmid DNA. Deep-sequencing of amplicons obtained from protoplast genomic DNA revealed that 6 to 22 percent of the target sites were mutated. The detected modifications comprised deletions in all three target sites and of various sizes, whereas insertions were observed in only one of the target genes (Vrs 1) and were confined to the size of 1 nucleotide. This study demonstrates the possibility of site-directed genome modification in Siberian barley. Further steps in technology advancement will require the development of protocols with reduced genotype dependence in terms of both the gene transfer to totipotent cells and the subsequent plant regeneration originating from such cells.

Key words: CRISPR/Cas; Cas9; barley; protoplasts; Nud; Vrs1; regeneration; transfection; site-directed mutagenesis; in vitro culture.

\section{Применение РНК-направленной} нуклеазы Cas9 для сайт-специфической модификации генома в протопластах сибирского сорта ячменя с высокой способностью к регенерации

\author{
С.В. Герасимова ${ }^{1,} 2$ 지, А.М. Короткова ${ }^{1}$, К. Хертиг ${ }^{3}$, \\ С. Хикель ${ }^{3}$, Р. Хофффи ${ }^{3}$, Н. БудхагатапалАи ${ }^{3}$, И. Отто ${ }^{3}$, \\ Г. Хенземь ${ }^{3}$, В.К. Шумный ${ }^{1}$, А.В. Кочетов ${ }^{1,2}, \breve{И . ~ К у м л е н ~}{ }^{3}$, \\ Е.К. Хиесткина ${ }^{1,2,4}$ \\ ${ }^{1}$ Федеральный исследовательский центр Институт цитологии и генетики \\ Сибирского отделения Российской академии наук, Новосибирск, Россия \\ ${ }^{2}$ Новосибирский национальный исследовательский государственный \\ университет, Новосибирск, Россия \\ 3 Институт генетики растений и исследования культурных растений \\ им. Лейбница, Гатерслебен, Германия \\ ${ }^{4}$ Федеральный исследовательский центр Всероссийский институт \\ генетических ресурсов растений им. Н.И. Вавилова (ВИР), \\ Санкт-Петербург, Россия
}

Модификация геномов культурных растений при помощи компонентов бактериальной защитной системы CRISPR/Cas в настоящее время является быстроразвивающейся областью прикладной науки. Методика индукции сайт-специфических изменений в растительных геномах, как правило, включает такие этапы, как конструирование генетических векторов, содержащих гены нуклеазы Cas9 и химерной направляющей РНК, доставку плазмидной ДНК или рибонуклеопротеиновых частиц в клетки растений, что приводит к внесению изменений в выбранный сайт геномной ДНК, и последующую регенерацию растений из модифицированных клеток. Применение этой технологии в селекции ограничено тем, что генотипы в разной степени подвержены генетической трансформации и различаются по способности к регенерации in vitro. Генотип-зависимость эффективности биотехнологических манипуляций особенно ярко выражена у культурных зерновых злаков. В настоящей работе была проведена оценка эффективности регенерации растений in vitro из клеток незрелых зародышей десяти сибирских сортов ячменя. Было показано, что только один из исследуемых сортов сопоставим с модельным для биотехнологических и генно-инженерных работ сортом Golden Promise. Сорт Алей продемонстрировал самую высокую эффективность регенерации среди сибирских сортов ячменя и был выбран для проведения эксперимента по модификации генома в протопластах мезофилла листа. Для проведения модификации генома было выбрано два целевых гена, которые контролируют хозяйственные признаки. Ген Nud контролирует признак голозерности или пленчатости, ген Vrs 1 - признак двурядности или шестирядности. Были сконструированы генетические век- 
торы, несущие систему модификации генома, направленную на три сайта в двух целевых генах. Конструкции были введены в протопласты методом полиэтиленгликоль-зависимой трансформации, детекция мутаций осуществлялась методом глубокого секвенирования целевых последовательностей, амплифицированных с геномной ДНК трансформированной клеточной популяции. Мутации были выявлены в 6-20 \% популяции трансформированных клеток. Делеции разного размера обнаружены в трех целевых сайтах, однонуклеотидные инсерции обнаружены только в одном из сайтов. Результаты, полученные в работе, демонстрируют возможность сайт-специфической модификации генома сибирского ячменя. Дальнейшие шаги по развитию технологии сайт-направленной модификации геномов культурных злаков потребуют разработки «генотип-независимых» методов генетической трансформации клеток и последующей регенерации растений из модифицированных клеток.

Ключевые слова: CRISPR/Cas; Cas9; ячмень; протопласты; Nud; Vrs 1; регенерация; трансфекция; сайт-направленный мутагенез; культивирование in vitro.

\section{HOW TO CITE THIS ARTICLE:}

Gerasimova S.V., Korotkova A.M., Hertig C., Hiekel S., Hoffie R., Budhagatapalli N., Otto I., Hensel G., Shumny V.K., Kochetov A.V., Kumlehn J., Khlestkina E.K. Targeted genome modification in protoplasts of a highly regenerable Siberian barley cultivar using RNA-guided Cas9 endonuclease. Vavilovskii Zhurnal Genetiki i Selektsii =Vavilov Journal of Genetics and Breeding. 2018;22(8):10331039. DOI 10.18699/VJ18.447

T argeted genome modification is a modern, particularly versatile tool to genetically engineer plants (amongst other organisms) (Gerasimova et al., 2017). There are a lot of reports of successful crop improvement using different applications of RNA-guided endonucleases (RGEN) which is also known as Cas endonuclease technology or CRISPR/Cas technology (Korotkova et al., 2017). Most of the published studies on barley targeted genome modification were performed on the model cultivar Golden Promise (Holme et al., 2017; Kapusi et al., 2017; Holubova et al., 2018; Kumar et al., 2018). To take full advantage of this technology for agricultural production, one needs to establish protocols for elite germplasm. In cereals however, the feasibility of genetic engineering is highly dependent on the genotype used (Kumlehn, Hensel, 2009). In the West Siberia region of the Russian Federation, barley occupies an area of three million hectares. The introduction of Cas endonuclease technology for breeding of Siberian varieties is a challenge, because effective protocols for in vitro regeneration, transformation and genome modifications of elite lines are yet to be established. The present study aims to select candidate barley cultivars for targeted genome modification and to demonstrate the modification of valuable trait-controlling genes in the genome of Siberian barley using Cas endonuclease technology. As first criterion for cultivar selection, recommendations of local breeders were considered. Next, a representative panel of pre-selected local cultivars was tested for efficient in vitro regeneration from immature embryos, which constitute the explant of choice for barley genetic engineering procedures. One cultivar from the Russian spring barley collection was eventually selected to conduct a genome modification experiment using mesophyll protoplasts. As targets, two previously known barley domestication genes controlling valuable traits in monogenic fashion were selected. The Nud gene controls hulled vs. naked barley (Taketa et al., 2008) and the Vrs 1 gene controls two-rowed vs. six-rowed barley (Pourkheirandish et al., 2015).

\section{Material and methods}

Plant material. The ten following West Siberian barley cultivars have been selected from the Russian spring barley collection according to the advice of local barley breeders: Biom, Talan, Vorsinskiy2, Aley, Acha, Signal, L-421, Kolchan, V-1, Krasnoyarskiy91. The model cultivar Golden Promise was used as a control with a high in vitro regeneration potential. Plants were grown under greenhouse conditions until milk or wax ripening stage of the caryopses.

Evaluation of in vitro regeneration efficiency. Milk or wax ripening stage spikes (stage $75-83$ of $\mathrm{BBCH}$ scale) were harvested; grains were isolated from spikes and sterilized by $96 \%$ ethanol for thirty seconds and bleach-surfactant solution (1:1 water dilution of Domestos, Unilever) for four minutes with subsequent washing in sterile water. Analysis was performed separately for five plants of each cultivar. For analysis, one-three spikes were taken from each plant, 10 to 13 immature embryos per plant were isolated. As a control the model barley cultivar Golden Promise was used.

After dissection and removal of the embryonic axis, embryos were plated scutellum side up on callus induction medium (4.3 g/l Murashige \& Skoog plant salt base, $30 \mathrm{~g} / 1 \mathrm{mal}-$ tose $\cdot \mathrm{H}_{2} \mathrm{O}, 1.0 \mathrm{~g} / 1$ casein hydrolysate, $\mathrm{CuSO}_{4} \cdot 5 \mathrm{H}_{2} \mathrm{O} 160 \mathrm{mg} / \mathrm{l}$, $350 \mathrm{mg} / \mathrm{l}$ myo-inositol, $690 \mathrm{mg} / \mathrm{l}$ proline, $1.0 \mathrm{mg} / \mathrm{l}$ thiamine $\cdot \mathrm{HCl}$, $2.5 \mathrm{mg} / \mathrm{l}$ Dicamba, $3.5 \mathrm{~g} / \mathrm{l}$ Phytagel, $\mathrm{pH}$ adjusted to 5.8 with $\mathrm{NaOH}$ ) and incubated at $22{ }^{\circ} \mathrm{C}$ in the dark (Harwood et al., 2009). After four weeks of cultivation on callus induction medium, calli were transferred to transition medium $(2.7 \mathrm{~g} / \mathrm{l} \mathrm{Mu}-$ rashige \& Skoog modified plant salt base [without $\mathrm{NH}_{4} \mathrm{NO}_{3}$ ], $20 \mathrm{~g} / \mathrm{l}$ maltose $\cdot \mathrm{H}_{2} \mathrm{O}, \mathrm{CuSO}_{4} \cdot 5 \mathrm{H}_{2} \mathrm{O} 160 \mathrm{mg} / \mathrm{l}, 165 \mathrm{mg} / \mathrm{lNH}_{4} \mathrm{NO}_{3}$, $750 \mathrm{mg} / \mathrm{l}$ glutamine, $100 \mathrm{mg} / \mathrm{l}$ myo-inositol, $0.4 \mathrm{mg} / \mathrm{l}$ thiamine $\cdot \mathrm{HCl}, 2.5 \mathrm{mg} / 1$ 2,4-dichlorophenoxy acetic acid, $0.1 \mathrm{mg} / \mathrm{l}$ 6-benzylaminopurine, $3.5 \mathrm{~g} / \mathrm{l}$ Phytagel, $\mathrm{pH}$ adjusted to 5.8) and were cultivated for another four weeks at $22{ }^{\circ} \mathrm{C}$ under low light. Then, calli were transferred to regeneration medium (2.7 g/l Murashige \& Skoog modified plant salt base [without $\left.\mathrm{NH}_{4} \mathrm{NO}_{3}\right], 20 \mathrm{~g} / \mathrm{l}$ maltose $\cdot \mathrm{H}_{2} \mathrm{O}, 165 \mathrm{mg} / 1 \mathrm{NH}_{4} \mathrm{NO}_{3}, 750 \mathrm{mg} / \mathrm{l}$ 
glutamine, $100 \mathrm{mg} / 1$ myo-inositol, $0.4 \mathrm{mg} / 1$ thiamine $\cdot \mathrm{HCl}$, $3.5 \mathrm{~g} / 1$ Phytagel, $\mathrm{pH} 5.8$ ) at $22{ }^{\circ} \mathrm{C}$ under full light (16/8 hours day/night). The number of explants giving rise to regenerated plants was counted after four weeks of growing at regeneration medium. The in vitro regeneration efficiency was calculated as percent of explants producing regenerating plants. The Mann-Whitney U test was performed for each Siberian cultivar for pairwise comparison to the control Golden Promise with regards to in vitro regeneration efficiency.

Target gene sequencing, guide-RNA design and vector construction. Genomic DNA was isolated from leaves of barley cv. Aley. A two cm-long piece of leaf was cut, transferred to the tube with $200 \mu$ of warm $\left(60{ }^{\circ} \mathrm{C}\right)$ buffer (100 mM Tris- $\mathrm{HCl} \mathrm{pH} 7.5-8.0,500 \mathrm{mM} \mathrm{NaCl}, 50 \mathrm{mM}$ EDTA, $1.25 \%$ SDS, $0.38 \% \mathrm{Na}_{2} \mathrm{~S}_{2} \mathrm{O}_{5}$ ) and ground in a homogenizer. Then, $500 \mu \mathrm{l}$ of buffer was added and incubated at $60^{\circ} \mathrm{C}$ for 30 minutes with subsequent addition of $700 \mu \mathrm{l}$ of chloroform-isoamyl alcohol mixture $(24: 1)$ and centrifugation at $12000 \mathrm{~g}$ for 25 minutes. The upper fraction was collected and mixed with $1.4 \mathrm{ml}$ of $96 \%$ ethanol. DNA was precipitated by centrifugation again at $12000 \mathrm{~g}$ for 25 minutes, washed with $70 \%$ ethanol and dissolved in TE buffer. Fragments corresponding to first exons of Nud (HORVU7Hr1G089930) and Vrs1 (HORVU2Hr1G092290) barley genes were amplified from genomic DNA using the primers Hv_Nud_1exF and Hv_Nud_1exR for the Nud gene and Hv_Vrs1_F1 and Hv_Vrs1_R1 for the Vrs1 gene (Suppl. Table) ${ }^{1}$. PCR fragments were subjected to Sanger sequencing. To confirm the identity of target sites in the Aley genome to known reference sequences (morex_contig 43456 CAJW010043456 carma= 7HL, morex_contig_135757 CAJW010135757 carma=2HL, barke contig_ 396030 CAJV010295100 carma=7HL, barke contig $6917 \overline{6}$ CAJV010052191, bowman contig $85076 \overline{6}$ CAJX010845871 carma=7HL, bowman_contig_16990 CAJX010016287), a pairwise alignment of sequenced $\mathrm{Nud}$ and Vrs 1 first exons was performed.

Target site selection was performed using the online tools DESKGEN (https://www.deskgen.com/landing/; Doench et al., 2016) and WuCRISPR (Wong et al., 2015). Guide-RNA secondary structures were modelled using the RNAfold tool (Gruber et al., 2008).

The generic vector pSH121 harboring maize codon-optimized Cas9 under control of Zea mays Ubiquitin-1 promoter and a guide-RNA scaffold preceded by the rice $U 3$ promoter was used as a backbone for final RGEN vector construction. To this end, pSH121 had been generated from pSH91 (Budhagatapalli et al., 2016) using a Gibson assembly approach (Gibson et al., 2009) in order to remove the necessity for a Guanine as starting nucleotide of the gRNA. The DNA molecules for the Gibson assembly were generated as followed: pSH91 was digested by HindIII restriction enzyme; DNA fragments were separated in agarose gel and the $10166 \mathrm{bp}$ fragment containing the Cas 9 expression cassette was isolated from the gel. Two additional DNA molecules with overhangs each compatible to the end of another DNA molecule used, were created in separate PCRs using pSH91 as template and either the oligonucleotide pair OsU3-1_GibF-OsU3-1_GibR or OsU3-1_GibF- OsU3-1_GibR (see Suppl. Table). The re-

\footnotetext{
Supplemantary Materials are available in the online version of the paper: http://www.bionet.nsc.ru/vogis/download/pict-2018-22/appx16.pdf
}

sulting 487 and 1633 bp amplicons were purified using the GeneJET PCR Purification Kit (Thermo Scientific). Gibson assembly of the three described DNA molecules was performed using the NEBuilder HiFi DNA Assembly Master Mix (NEB) according to the manufacturers instructions.

The target-specific ca. 20 bp region of the gRNA can be inserted into pSH121 vector between two $B s a \mathrm{I}$ restriction sites as a double-stranded oligonucleotide with 5 '-overhang tails. Double-stranded oligos were created by melting and reannealing the following pairs of oligonucleotides: Nud_ex1-45-F and Nud_ex1-45-R, Nud_ex1-50-F and Nud_ex1-50-R, Vrs1_ex133-F and Vrs1_ex1-33-R (see Suppl. Table). pSH121 was digested by $B s \bar{a}$ I restriction enzyme; DNA fragments were separated in agarose gel. The $10972 \mathrm{bp}$ fragment was eluted from a gel and used in three ligation reactions with doublestranded oligonucleotides. As a result of ligation, three RGEN vectors VRS1-33RGEN, NUD-45RGEN and NUD-50RGEN were assembled. The accuracy of construct assembly was confirmed by Sanger sequencing.

Protoplast isolation and transformation. Grains were germinated in the dark at $23{ }^{\circ} \mathrm{C}$. Leaf samples from seven days-old etiolated seedlings were used for protoplast isolation. Protoplasts were isolated according to Q. Shan et al. (2014). Protoplast sample quality and cell population density were estimated in a counter chamber slide using a microscope. A total amount of $20 \mu \mathrm{g}$ plasmid DNA consisting of gRNA/Cas9 transformation vector and GFP expression vector pYF133 (Fang et al., 2002) was taken to transform $5 \times 10^{5}$ protoplasts in $220 \mu \mathrm{l}$ volume. PEG-mediated transfection was performed according to Q. Shan et al. (2014). After two days of incubation at $21^{\circ} \mathrm{C}$, the transformed protoplasts were observed using an inverted fluorescence microscope (Zeiss Axiovert 200M, filter set 13 with excitation wavelength BP 470/20 and emission wavelength BP 505-530). The proportion of GFP-positive cells was calculated per counting field of the chamber slide to provide a metric for transformation efficiency.

DNA isolation, library preparation, deep amplicon sequencing analysis. Genomic DNA was isolated from protoplast samples by the method described by W. Wang et al. (2016). For each gene, specific primers were designed to amplify target loci from protoplast genomic DNA. Target fragments were amplified using primer pairs Hv_Nud_F4Hv_Nud_1exR and Hv_Vrs1_1exF-Hv_Vrs1_1exR for $\mathrm{Nud}$ and $\operatorname{Vrs} \overline{1}$ genes, respectively (see Suppl. Table). Amplicon barcoding and library preparation was performed according to recommendations of the service provider for amplicon sequencing (https://en.novogene.com/next-generation-sequencing-services/microbial-genome/amplicon-sequencing/). Sequencing was performed using the Illumina HiSeq platform generating paired-end $250 \mathrm{bp}$ reads. After filtration, the sequence depth ranged from 6000 to 8000 reads per amplicon sample. The indel frequency and patterns induced by VRS133RGEN, NUD-45RGEN and NUD-50RGEN vectors were analyzed. The threshold for mutation detection was adjusted to the level of one percent. Indel frequency was normalized to the control GFP vector co-transformation efficiency.

\section{Results}

Cultivar selection. The regeneration test was performed in order to select the candidate cultivars for further establishment 
$a$

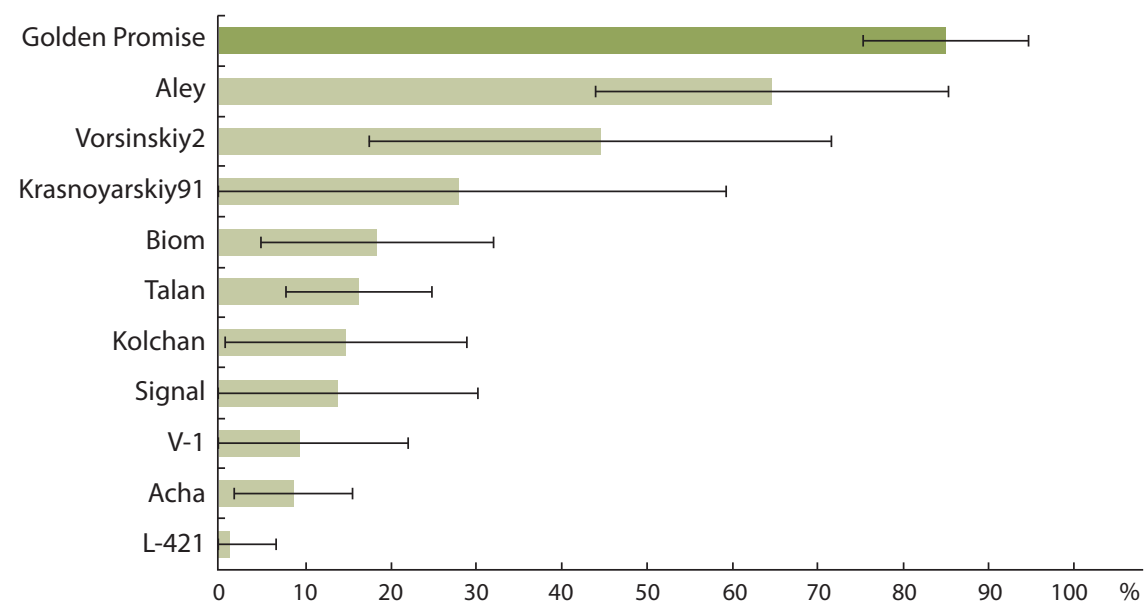

$b$

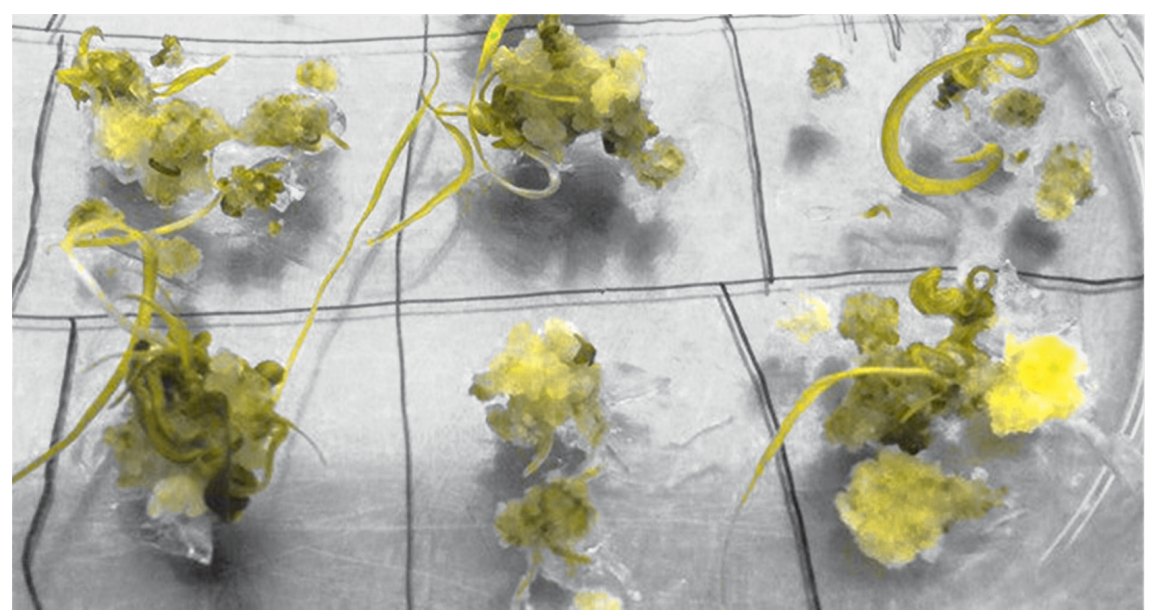

Fig. 1. In vitro regeneration from immature embryos of 10 Siberian barley cultivars in comparison to the model cultivar Golden Promise.

$a$ - numbers represent percent of explants producing regenerated plants. Horizontal bars represent standard deviation; $b$ - plantlet regeneration from callus of the Siberian barley cultivar Aley.

of targeted genome modification protocols. A standard protocol for Agrobacteriummediated barley transformation using immature embryos (Harwood et al., 2009) was adopted and control regeneration tests with neither Agrobacterium inoculation nor use of selective agents were performed. Fig. 1 (a) shows the percentage of explants which gave rise to regenerated plants. Nine out of ten Siberian barley cultivars showed significantly $(p<0.05)$ lower regeneration efficiency than the model cultivar Golden Promise, whereas only one cultivar from the experimental group did not differ significantly $(p>0.05)$ from this control. Aley evidently performed best across all experimental repetitions showing an overall efficiency over $60 \%$ (see Fig. 1). Consequently, this cultivar was chosen for the following genome modification experiment.

Target site selection and vector construction. The barley genes $\mathrm{Nud}$ and $\mathrm{Vrs} 1$ were selected for targeted mutagenesis. To reveal the sequence of these genes in the Siberian cultivar Aley, specific primers were designed based on the barley reference sequence and a fragment containing the first exon of the respective gene was amplified and sequenced. Alignment to Nud and Vrs 1 sequences available in databases showed high identity of the Aley gene variants to the reference (Suppl. Figure). Target sites were selected in the first exon of each gene, two sites for Nud and one for Vrs1. The generic vector pSH121 (Fig. 2, a) was used to generate the three target-specific vectors used for transformation experiments (Table 1).
Evaluation of genome modifications in protoplasts. Protoplasts were isolated from seedlings of barley cv. Aley and co-transformed with two vectors, more specifically, any one of the RGEN vectors and the control vector pYF133 harboring a GFP expression cassette (see Fig. 2, $a$ and $b$ ). Anticipating that the transformation efficiency of the co-transformed GFP plasmid is equal to that of the gRNA/Cas9 vector, the proportion of green fluorescing cells was used to normalize the cleavage activity of the respective guide-RNA tested (Lin et al., 2018). Genomic DNA was isolated from protoplasts and used as a template for the amplification of target sequences. Mutations were detected in each target site and occurred with different frequency (Table 2, Fig. 2, c). The Nud-45 guide-RNA showed the highest efficiency in this experiment $(22 \%)$. There were only few mutation types detected for each target site (see Fig. 2,c). Three different deletion sizes were detected for the Nud-45 target site $(-1,-2$ and -9 nucleotides $)$, two deletion sizes for the Nud-50 target site ( -5 and $-6 \mathrm{nt})$ as well as one deletion and one insertion size for the Vrs1-33 target site $(-3$ and $+1 \mathrm{nt})$.

\section{Discussion}

Little is known about the mechanisms which are causative for the high genotype dependence of genetic engineering. Most available reports of targeted barley genome modifications describe mutations in the Golden Promise genome. We aimed to demonstrate successful targeted genome modifications in cells of a non-model elite Siberian barley cultivar. The protoplast system is a well established tool for assessing the efficiency of targeted genome modifications in plants. The evaluation of RGEN cleavage efficacy in vivo allows one to select the best variants of target site/guide RNA pairs (Budhagatapalli et al., 2016).

We selected two target genes controlling domestication traits in barley. The Nud and Vrs1 genes control hulled vs. naked and two rowed $v s$. six rowed barley variants, respectively. The selected $\mathrm{cv}$. Aley features a hulled and two-rowed phenotype and its genome contains wildtype alleles of both genes. Two sites in the Nud and one site in the Vrsl coding sequence were targeted. 
Table 1. Target sites, target-specific parts of guide-RNAs and transformation vectors (PAM, protospacer-adjacent motif; CDS, coding sequence)

\begin{tabular}{ccccc}
\hline Gene & Target site with PAM (underlined) & Target position in the CDS & Target-specific part of guide-RNA & Final vector \\
\cline { 1 - 4 } Nud & GGAGACCCAGGAGCCCCAGTGG & $45-64$, exon 1 & GGAGACCCAGGAGCCCCAG & NUD-45RGEN \\
\hdashline Nud & GCTCCTGGGTCTCCGAGATCAGG & $50-69$, exon 1 & GCTCCTGGGTCTCCGAGATC & NUD-50RGEN \\
\hdashline Vrs 1 & GTGGACACGACTTTCTTCGCGG & $33-52$, exon 1 & GTGGACACGACTTTCTTCG & VRS1-33RGEN
\end{tabular}

$a$

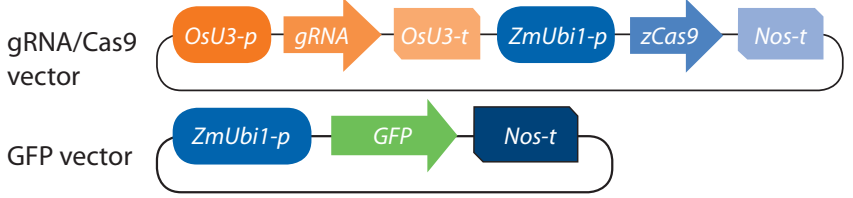

$b$

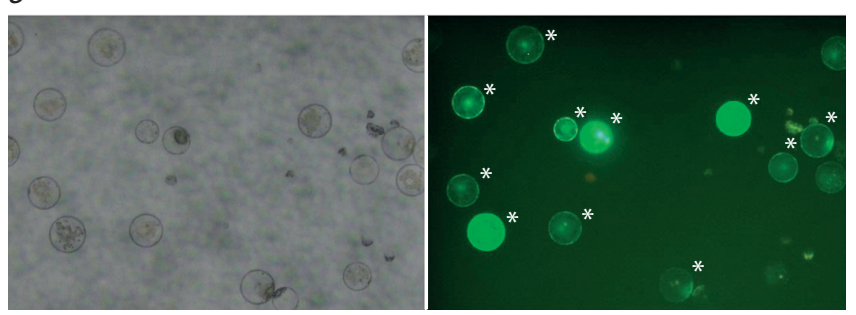

Nud-45
WT
d1
d2
d9

CGCGGCGTCAGGCAGCGCCACTGGGGCTCCTGGGTCTCCGAGATCAGGCATCCTCTCCT CGCGGCGTCAGGCAGCGCCACTG-GGCTCCTGGGTCTCCGAGATCAGGCATCCTCTCCT CGCGGCGTCAGGCAGCGCCACTG--GCTCCTGGGTCTCCGAGATCAGGCATCCTCTCCT CGCGGCGTCAGGCAGCGCCACTG-------GGTCTCCGAGATCAGGCATCCTCTCCT

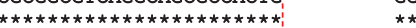

Nud-50

WT CGCGGCGTCAGGCAGCGCCACTGGGGCTCCTGGGTCTCCGAGATCAGGCATCCTCTCCT d5 CGCGGCGTCAGGCAGCGCCACTGGGGCTCCTGGGTCT-----AATCAGGCATCCTCTCCT d6 CGCGGCGTCAGGCAGCGCCACTGGGGCTCCTGGGTC-----ATCAGGCATCCTCTCCT CG:G

Vrs1-33

WT ATGGACAAGCATCAGCTCTTTGGTTCATCCAACGTGGACACGACTTTCT TCGCGGCCA d3 ATGGACAAGCATCAGCTCTTTGGTTCATCCAACGTGGACACGACTT--- TCGCGGCCA i1 ATGGACAAGCATCAGCTCTTTGGTTCATCCAACGTGGACACGACTTTCTMTCGCGGCA

Fig. 2. Protoplast transformation and detection of site-directed mutations.

$a$ - vector architectures used for protoplast transformation; gRNA/Cas9 vector corresponds to pSH121; GFP vector - to pYF133; OsU3- $p$ - rice U3 promoter; gRNA - chimeric guide RNA; OsU3-t - rice U3 terminator element; ZmUbi1- $p$ - maize Ubiquitin-1 promoter; $z$ Cas9 - maize codon-optimized Cas9 endonuclease; Nos- $t$ - 3'-signal of nopaline synthase gene; $b$ - GFP detection in transformed protoplasts; bright field (left) and GFP filter (right). GFP-positive cells are marked with asterisk; $c$ - mutation types obtained in Aley protoplasts for the three target sites (marked blue, PAM in red).

Table 2. Mutation detection in protoplasts with the given mutation frequencies being normalized to transformation efficiency

\begin{tabular}{|c|c|c|c|c|c|}
\hline Guide-RNA & $\begin{array}{l}\text { Total number } \\
\text { of reads }\end{array}$ & $\begin{array}{l}\text { Transformation } \\
\text { efficiency }\end{array}$ & Mutation type ${ }^{*}$ & $\begin{array}{l}\text { Number of reads } \\
\text { with mutation }\end{array}$ & $\begin{array}{l}\text { Mutation } \\
\text { frequency, \% }\end{array}$ \\
\hline \multirow[t]{3}{*}{ Nud-45 } & \multirow[t]{3}{*}{6758} & \multirow[t]{3}{*}{0.66} & $-G(-1)$ & 691 & 15.5 \\
\hline & & & $-G G(-2)$ & 210 & 4.7 \\
\hline & & & -GGGCTCCTG (-9) & 81 & 1.8 \\
\hline \multirow[t]{2}{*}{ Nud-50 } & \multirow[t]{2}{*}{7821} & \multirow[t]{2}{*}{0.46} & -CTCGGA (-6) & 158 & 4.4 \\
\hline & & & -CTCGG (-5) & 112 & 3.1 \\
\hline \multirow[t]{2}{*}{ Vrs1-33 } & \multirow[t]{2}{*}{6553} & \multirow[t]{2}{*}{0.35} & $-\operatorname{TTC}(-3)$ & 74 & 3.2 \\
\hline & & & $+\mathrm{T}(+1)$ & 66 & 2.9 \\
\hline
\end{tabular}

* Number of inserted or deleted nucleotides is indicated in parenthesis.

Aley protoplast transformation efficiency was estimated from the proportion of GFP-positive cells which ranged from 0.35 to 0.66 . This result is well comparable with previously published data (Bai et al., 2014; Lin et al., 2018). For all three selected target sites, mutated variants were obtained at frequencies of 6 to $22 \%$ (normalized to transformation efficiency). There is no published data of targeted genome modification efficiency in barley protoplasts, but in comparison to other Poaceae family species, comparable mutation frequencies were obtained (Lin et al., 2018). However, the diversity of mutation types seen in the present study is comparatively low. There was no predominant type of mutations common for all target sites, i.e. mutation patterns were different for each particular case. We assume that the mutation type depends on target site properties; for example, the 9-nucleotides deletion of the Nud-45 site and the three nucleotides deletion for Vrs1-33 site might be due to sequence-specific microhomologies, and the insertion of T to Vrs1-33 site could be due to the reconstruction of a short CTTT repeat within the target site.

Our data show that RGEN-mediated genome modification is possible in cells of Siberian barley. To obtain plants of desirable genotypes with predefined genome modifications, 
the genotype dependency of gene transfer mechanisms and in vitro regeneration has to be considerably reduced.

The number of genotypes hitherto engineered using Cas endonuclease technology is highest in rice (45 genotypes), which is followed by tomato (10), wheat (7), potato (4), oilseed rape (3), and further by switchgrass, soybean, maize, grapes and cucumbers with two genotypes per crop, and finally by barley, orange, grapefruit, apple, flax and cotton with only one genotype per crop (Korotkova et al., 2019). Further development of Cas endonuclease technology and its broad application potential for crop improvement requires involvement of more genotypes and varieties. Our results reveal a wide range of in vitro regeneration efficiency for a preselected group of 10 Siberian barley cultivars. Only one out of ten cultivars is comparable in regeneration efficiency with model cultivar Golden Promise. Aley is our current prime candidate cultivar for further establishment of stable genetic transformation. Identification of transformation amenability loci in the genome of Golden Promise and introduction of respective alleles into genomes of elite cultivars via marker-assisted selection has been suggested to create elite germplasm with increased transformation amenability (Hisano et al., 2017). Another approach may involve a transient overexpression of genes which enhance cellular totipotency. The maize Baby boom (Bbm) and Wuschel2 (Wus2) genes were successfully used to stimulate transformation in maize and sorghum (Lowe et al., 2016, 2018). Further studies on the genetic control of barley transformation and regeneration ability and the utilization of known "transformation amenability" genes in genetic engineering experiments may facilitate the transition from fundamental research to practical applications.

\section{Conclusion}

Our study demonstrates the technical limitations of RGEN application for local cultivars. We showed that only a small portion of Siberian elite barley cultivars has useful in vitro regeneration ability. At the same time, we demonstrated at the cellular level that important genes of a local Siberian cultivar can readily be modified at predefined target motifs by Cas endonuclease technology. These results indicate that further work in the field of crop improvement has to be focused on developing efficient genetic engineering and in vitro regeneration systems and/or straightforward and universally useful methods for Cas9/gRNA delivery and targeted genome modification without the necessity of in vitro regeneration.

\section{Acknowledgements}

This study was supported by the Russian Science Foundation, project No. 16-14-00086.

\section{Conflict of interest}

The authors declare no conflict of interest.

\section{References}

Bai Y., Han N., Wu J., Yang Y., Wang J., Zhu M., Bian H. A transient gene expression system using barley protoplasts to evaluate microRNAs for post-transcriptional regulation of their target genes. Plant Cell Tiss. Organ Cult. (PCTOC). 2014;119(1):211-219. DOI 10.1007/s11240-014-0527-z.

Budhagatapalli N., Schedel S., Gurushidze M., Pencs S., Hiekel S., Rutten T., Kusch S., Morbitzer R., Lahaye T., Panstruga R., Kum- lehn J., Hensel G. A simple test for the cleavage activity of customized endonucleases in plants. Plant Methods. 2016;12:18. DOI 10.1186/s13007-016-0118-6.

Doench J.G., Fusi N., Sullender M., Hegde M., Vaimberg E.W., Donovan K.F., Smith I., Tothova Z., Wilen C., Orchard R., Virgin H.W., Listgarten J., Root D.E. Optimized sgRNA design to maximize activity and minimize off-target effects of CRISPR-Cas9. Nat. Biotechnol. 2016;34(2):184-191. DOI 10.1038/nbt.3437.

Fang Y.D., Akula C., Altpeter F. Agrobacterium-mediated barley (Hordeum vulgare L.) transformation using green fluorescent protein as a visual marker and sequence analysis of the T-DNA::barley genomic DNA junctions. J. Plant Physiol. 2002;159:1131-1138. DOI 10.1078/0176-1617-00707.

Gerasimova S.V., Khlestkina E.K., Kochetov A.V., Shumny V.K. Genome editing system CRISPR/Cas9 and peculiarities of its application in monocots. Russ. J. Plant Physiol. 2017;64(2):141-155. DOI 10.1134/S1021443717010071.

Gibson D.G., Young L., Chuang R.Y., Venter J.C., Hutchison C.A. 3rd, Smith H.O. Enzymatic assembly of DNA molecules up to several hundred kilobases. Nat. Methods. 2009;6:343-345. DOI 10.1038/ nmeth.1318.

Gruber A.R., Lorenz R., Bernhart S.H., Neuböck R., Hofacker I.L. The Vienna RNA websuite. Nucleic Acids Res. 2008;36(Web Server issue):W70-W74. DOI 10.1093/nar/gkn188.

Harwood W.A., Bartlett J.G., Alves S.C., Perry M., Smedley M.A., Leyland N., Snape J.W. Barley transformation using Agrobacteriummediated techniques. Methods Mol. Biol. 2009;478:137-147. DOI 10.1007/978-1-59745-379-0_9.

Hisano H., Meints B., Moscou M.J., Cistue L., Echávarri B., Sato K., Hayes P.M. Selection of transformation-efficient barley genotypes based on TFA (transformation amenability) haplotype and higher resolution mapping of the TFA loci. Plant Cell Rep. 2017;36(4):611620. DOI 10.1007/s00299-017-2107-2.

Holme I.B., Wendt T., Gil-Humanes J., Deleuran L.C., Starker C.G., Voytas D.F., Brinch-Pedersen H. Evaluation of the mature grain phytase candidate HvPAPhy_a gene in barley (Hordeum vulgare L.) using CRISPR/Cas9 and TALENs. Plant Mol. Biol. 2017;95(1-2):111121. DOI 10.1007/s11103-017-0640-6.

Holubova K., Hensel G., Vojta P., Tarkowski P., Bergougnoux V., Galuszka P. Modification of barley plant productivity through regulation of cytokinin content by reverse-genetics approaches. Front. Plant Sci. 2018;9:1676. DOI 10.3389/FPLS.2018.01676.

Kapusi E., Corcuera-Gómez M., Melnik S., Stoger E. Heritable genomic fragment deletions and small indels in the putative ENGase gene induced by CRISPR/Cas9 in barley. Front. Plant Sci. 2017;8:540. DOI 10.3389/fpls.2017.00540.

Korotkova A.M., Gerasimova S.V., Khlestkina E.K. Current achievements in modifying crop genes using CRISPR/Cas system. Vavilovskii Zhurnal Genetiki i Selektsii = Vavilov Journal of Genetics and Breeding. 2019. (In press).

Korotkova A.M., Gerasimova S.V., Shumny V.K., Khlestkina E.K. Crop genes modified using the CRISPR/Cas system. Russ. J. Genet.: Appl. Res. 2017;7(8). DOI 10.1134/S2079059717050124.

Kumar N., Galli M., Ordon J., Stuttmann J., Kogel K.H., Imani J. Further analysis of barley MORC1 using a highly efficient RNA-guided Cas9 gene-editing system. Plant Biotechnol. J. 2018;16(11):18921903. DOI 10.1111/pbi.12924.

Kumlehn J., Hensel G. Genetic transformation technology in the Triticeae. Breed. Sci. 2009;59:553-560. DOI 10.1270/jsbbs.59.553.

Lin C.S., Hsu C.T., Yang L.H., Lee L.Y., Fu J.Y., Cheng Q.W., Wu F.H., Hsiao H.C.W., Zhang Y., Zhang R., Chang W.J., Yu C.T., Wang W., Liao L.J., Genvin S.B., Shih M.C. Application of protoplast technology to CRISPR/Cas9 mutagenesis: from single-cell mutation detection to mutant plant regeneration. Plant Biotechnol. J. 2018;16(7): 1295-1310. DOI 10.1111/pbi.12870.

Lowe K., La Rota M., Hoerster G., Hastings C., Wang N., Chamberlin M., Wu E., Jones T., Gordon-Kamm W. Rapid genotype "independent" Zea mays L. (maize) transformation via direct somatic 
embryogenesis. In Vitro Cell. Dev. Biol. Plant. 2018;54(3):240-252. DOI 10.1007/s11627-018-9905-2.

Lowe K., Wu E., Wang N., Hoerster G., Hastings C., Cho M.J., Scelonge C., Lenderts B., Chamberlin M., Cushatt J., Wang L., Ryan L., Khan T., Chow-Yiu J., Hua W., Yu M., Banh J., Bao Z., Brink K., Igo E., Rudrappa B., Shamseer P.M., Bruce W., Newman L., Shen B., Zheng P., Bidney D., Falco C., Register J., Zhao Z.Y., Xu D., Jones T., Gordon-Kamm W. Morphogenic regulators Baby boom and Wuschel improve Monocot transformation. Plant Cell. 2016;28(9):1998-2015. DOI 10.1105/tpc.16.00124.

Pourkheirandish M., Hensel G., Kilian B., Senthil N., Chen G., Sameri M., Azhaguvel P., Sakuma S., Dhanagond S., Sharma R., Mascher M., Himmelbach A., Gottwald S., Nair S.K., Tagiri A., Yukuhiro F., Nagamura Y., Kanamori H., Komatsuda T. Evolution of the grain dispersal system in barley. Cell. 2015;162(3):527-539. DOI 10.1016/J.CELL.2015.07.002.
Shan Q., Wang Y., Li J., Gao C. Genome editing in rice and wheat using the CRISPR/Cas system. Nature Protoc. 2014;9(10):2395-2410. DOI 10.1038/nprot.2014.157.

Taketa S., Amano S., Tsujino Y., Sato T., Saisho D., Kakeda K., Nomura M., Suzuki T., Matsumoto T., Sato K., Kanamori H., Kawasaki S., Takeda K. Barley grain with adhering hulls is controlled by an ERF family transcription factor gene regulating a lipid biosynthesis pathway. Proc. Natl. Acad. Sci. USA. 2008;105(10):4062-4067. DOI 10.1073/pnas.0711034105.

Wang W., Akhunova A., Chao S., Akhunov E. Optimizing multiplex CRISPR/Cas9-based genome editing for wheat. BioRxiv. DOI 10.1101/051342.

Wong N., Liu W., Wang X. WU-CRISPR: characteristics of functional guide RNAs for the CRISPR/Cas9 system. Genome Biol. 2015;16: 218. DOI 10.1186/s13059-015-0784-0.

\section{ORCID ID}

S.V. Gerasimova orcid.org/0000-0001-8626-1831

C. Hertig orcid.org/0000-0002-2320-7579

S. Hiekel orcid.org/0000-0001-7649-3989

R. Hoffie orcid.org/0000-0003-1013-6027

N. Budhagatapalli orcid.org/0000-0002-5537-8276

G. Hensel orcid.org/0000-0002-5539-3097

J. Kumlehn orcid.org/0000-0001-7080-7983

E.K. Khlestkina orcid.org/0000-0002-8470-8254 